Article

\title{
The Influence of Liberalization on Innovation, Performance, and Competition Level of Insurance Industry in Indonesia
}

\author{
Tulus Suryanto ${ }^{1, * \mathbb{C}}$, Darul Dimasqy ${ }^{2}$, Reza Ronaldo ${ }^{3}$, Mahjus Ekananda ${ }^{4}$, Teuku Heru Dinata ${ }^{2}$ \\ and Indra Tumbelaka ${ }^{2}$ \\ 1 Faculty of Economics and Islamic Business, Raden Intan State Islamic University of Lampung, \\ Bandar Lampung 35131, Indonesia \\ 2 Departement of Research in Financial Service, Sector Financial Service Authority (OJK), \\ Jakarta Pusat 10710, Indonesia; darul.dimasqy@ojk.go.id (D.D.); teuku.heru@ojk.go.id (T.H.D.); \\ indra_t@ojk.go.id (I.T.) \\ 3 College of Islamic Economics and Business (STEBI) Lampung, Pesawaran 35371, Indonesia; \\ rezaronaldo@stebilampung.ac.id \\ 4 Department of Economics, Faculty of Economics \& Business, University of Indonesia, \\ Depok 16424, Indonesia; m.ekananda@gmail.com \\ * Correspondence: tulus@radenintan.ac.id
}

Received: 16 October 2020; Accepted: 15 December 2020; Published: 18 December 2020

check for updates

\begin{abstract}
This study aims to reveal the impact of liberalization on innovation, performance, and the level of competition for insurance industry players in Indonesia based on insurance data from 2006 to 2018. The research method used is quantitative with the support of panel data. The analysis technique to explain the findings uses an aggregate model and Threshold Regression analysis. Descriptive and econometric research types were chosen to make it easier to explain the findings. From the results of data analysis using three experimental models, it shows three findings. First, in the aggregate, there is a significant negative relationship between liberalization and innovation. In the Threshold Regression model, a negative impact occurs on companies with low premium income, whereas in high premium income companies, the result is positive. This is due to the availability of resources to large companies to optimize the adaptation of liberalization in terms of innovation. Second, higher liberalization can encourage insurance companies to perform more efficiently and increase net premium income. Third, the negative impact of liberalization on competition shows that the higher the deregulation, the lower the game. These findings indicate that in the aggregate, global insurance financial liberalization has had a significant impact on the development of the insurance industry sector in Indonesia. However, liberalization can be different for groups of small companies and groups of large companies. The expected implication is that the government needs to adopt a long-term policy strategy that can encourage the sustainability of insurance companies: both high-income companies and low-premium-income companies. Besides this, it is hoped that insurance companies pay more attention to innovation, significantly improving the quality of human resources as a competitive advantage in facing global competition.
\end{abstract}

Keywords: competition; innovation; insurance; liberalization; performance

\section{Introduction}

In terms of capital provisions, the Indonesian insurance industry is quite open to foreign investors. Based on the requirements of Government Regulation Number 14 of 2018 concerning Foreign Ownership in Insurance Companies, which was later amended by Government Regulation Number 3 of 2020 
regarding Amendments to Government Regulation Number 14 of 2018 relating to Foreign Ownership in Insurance Companies, the maximum limit of ownership of insurance companies by foreign parties is up to $80 \%$ of the paid-up capital. Also, this provision is exempt for public companies and insurance companies, which, at the time of stipulation, are owned by foreign parties with an ownership percentage of more than $80 \%$. These provisions are still more lenient than similar conditions in other ASEAN countries such as Thailand and Malaysia. In this case, the two countries set the maximum foreign ownership requirement of $25 \%$ and $70 \%$, respectively [1].

Insurance services have a central role in modern society. The empirical evaluation of competition among insurance companies also improved after deregulation [2]. After liberalization, the amount of insurance in the market began to increase, which led to a significant decrease in market concentration [3]. At the ideal level, liberalization adaptation can have a positive impact on the development of the insurance industry in a country [4-8]. The impact of liberalization is initially U-shaped during contraction and is linear, but in the second period, it seems that liberalization is superior to before it implemented [9].

Liberalization can provide benefits in supporting the special skills needed to encourage competency improvement of the insurance industry players whose development is still at an early stage [2]. The findings differ from previous studies, which revealed that financial liberalization has an inverse impact on the performance of insurance companies. The existence of liberalization has encouraged most insurance companies, consisting of 1324 companies registered with The Organization for Economic Co-operation and Development (OECD), to take more risks to survive [10]. The negative impact of liberalization is due to ineffective and inefficient ways of developing and government policies in the insurance sector [11]. The liberalization of policies in the insurance industry has increased the risk of using funds, and this is a significant difficulty facing the insurance industry [12].

In the insurance industry, board composition has a positive relationship with the overall risk-taking of a company [13]. Besides this, specific expertise support can obtain through the assignment of foreign workers with qualifications in actuarial and insurance management, which is possible due to foreign company owners who are more experienced in managing insurance companies in a relatively mature market [14]. Also, foreign participation can provide much-needed capital support for industry players to explore market potentials that have not optimal exploited.

Through technical support and capital capacity, liberalization expects to have a positive impact in the form of opportunities for innovation in the use of information technology aimed at increasing the effectiveness and efficiency of the insurance company's business processes [7]. One example of innovation in information technology includes online marketing of insurance products, for example, by utilizing e-commerce platforms. Also, information technology can be used by insurance companies to provide convenience for consumers in the underwriting process and increase the speed of the claim process.

Meanwhile, from a customer perspective, liberalization can also provide benefits in developing a more competitive insurance market. The increase in the intensity of competition among insurance industry players expects a stimulus to increase the availability of quality insurance services to customers at affordable premium rates. Society wants an insurance liberalization that leads to continuous innovation and improvement [15].

However, the positive impact of liberalization on the development of the insurance industry in Indonesia is still not optimal. Insurance is currently not considered an essential indicator of a market economy, a source of investment, and economic stability required for its development [11]. There are indications that the level of liberalization of the insurance industry in Indonesia is not directly proportional to the performance of the sector, especially when compared to other countries, especially in the ASEAN region. As an illustration, the estimated value of Indonesia's insurance premiums in 2018, amounting to USD 20,383 million, is still behind when compared to the estimated premium value of Thailand in the same period, which is USD 26,622 million (Swiss Re Institute, 2019) [16]. 
If the stakeholders do not respond wisely and with the right strategy, liberalization becomes a challenge for stakeholders [6].

The main challenge for the insurance industry is increasing market competition [17]. Apart from that, Indonesia is still lagging behind the two countries regarding density and insurance penetration. Based on Swiss Re data, Indonesia's insurance density is ranked 72 (seventy-two) globally with a value of USD 76 per capita, while Malaysia and Thailand were respectively ranked 39 (thirty-nine) and 47 (forty-seven), with a much higher density value of USD 518 and USD 385. When viewed based on insurance penetration indicators, Indonesia also lags behind the two countries and even ranks lower than Vietnam [16].

This is related to the Generalized System Preferences Review (GSP Review) process, the impact of the negotiation process with the United States and the United Kingdom. Indonesia is faced with a difficult choice to implement a broader liberalization of international trade by imposing relaxation on mandatory arrangements. The minimum limit of self-retention and placement of domestic reinsurance has been enacted for domestic insurance companies. Thus, the future policy direction will open up more expansive space for domestic insurance companies in terms of managing their risks and in terms of organizing reinsurance transactions with reinsurance partners abroad.

Indonesia needs to continue to liberalize the insurance industry sector. Financial Services Authority $(\mathrm{OJK})$ and the insurance industry players in Indonesia need to formulate a regulatory framework and business management strategy that can optimize the benefits of this liberalization trend. At the same time, it is important to anticipate potential negative impacts due to the liberalization of the insurance industry on domestic industry players and the national economy.

Previous research analyzed the impact of liberalization through indicators of the marketing mix, service quality, and insurance awareness [8]. Other findings were made to see the development of the insurance market and the liberalization of the financial system on bank performance [18-20]. Financial liberalization has resulted in the fragility of the banking sector with a strong institutional environment [21]. Most of the research on insurance liberalization has been carried out in India [22-24], for example, in the analysis of the performance of insurance companies during the liberalization period in India [25]. Research on the impact of liberalization has also been conducted in Korea, Bangladesh, Nepal, the Philippines, Taiwan, Malaysia, and Thailand [26,27]. Liberalization and capacity building for insurance services in Africa, excluding South Africa, was found to have the lowest regional insurance penetration in the world [28]. Few literature reviews examine the impact of insurance liberalization in Indonesia. Unlike previous studies, the main objective of this study is to determine the effect of liberalization using a research model consisting of innovation, performance, and competition that focuses on the following: (1) innovation in the use of information technology in the fields of sales, staffing, and education carried out by insurance companies; (2) performance of insurance companies; (3) the intensity of the performance of the insurance company, and (4) produce recommendations and/or business management strategies that can optimize the use of liberalization to encourage industrial growth in Indonesia.

\section{Materials and Methods}

Quantitative Method: This research was conducted using quantitative research methods. The analysis strategy used to answer the problem formulation is descriptive and econometric analysis. Threshold Autoregressive (TAR) analysis uses time-series data with the support of panel data from all insurance companies in Indonesia. TAR aims to deepen the study for various regimes for certain economic variables using the dummy method [29]. In conducting the panel data estimation method, the rule of thumb method was used [30]. Regression analysis was used to identify the relationship between insurance liberalization and innovation, in the form of technology use in the insurance company process, insurance company performance, and the level of competition in the insurance industry sector on liberalization. The proposed econometric model is an innovation model influenced by liberalization, and the internal variables of Insurance (IntInsVar) and macroeconomic variables (MacVar) were used 
as control variables. The insurance financial liberalization index represents the liberalization variable. The methods and experiments in modeling are as follows:

Model I: Innovation

$$
\text { Innovation }_{j t}=\mathrm{f}\left(\text { liberalization }_{j t}, \operatorname{IntInsVar}_{t}, \operatorname{MacVar}_{i t}\right)
$$

Model II: Competition

$$
\text { Comp }_{i t}=\mathrm{f}\left(\text { liberalization }_{i t}, \operatorname{IntInsVar}_{i t}, \operatorname{MacVar}_{i t}\right)
$$

Model III: Performance

$$
\text { Performance }_{i t}=\mathrm{f}\left(\text { liberalization }_{i t}, \text { IntInsVar3 }_{i t}, \operatorname{MacVar}_{i t}\right)
$$

* Variable IntInsVar ${ }_{t}$ consists of sales innovation, worker innovation, and educational innovation.

a. Variable $\mathrm{MacVar} t$ consists of:

(1) Variable $I N F_{t}$, the price of goods is measured by changes in the consumer index that can reflect changes in the prices of goods and services from people's needs, which uses as parameters for changes in economic activity.

(2) Variable $g P D B_{t}$ (Gross Domestic Product growth) is the increase in the amount of added value generated by all business units in a particular country, or is the total value of final goods and services produced by all economic companies used as a parameter of changes in economic activity.

(3) Variable Credit interest rates $\left(S B_{t}\right)$ are policy interest rates that reflect the monetary policy stance or stance set by Bank Indonesia, which is used as a parameter that leads to volatility in money market interest rates, which then leads to changes in premiums, especially for tips.

b. Variable $L i b_{t}$ is the Liberalization Insurance index measuring liberalization (ILI).

Model 1 explains the impact of liberalization on innovation assuming the internal variables of insurance companies and the impact of macro variables as control variables. Increased liberalization shows that companies are increasingly intensively using resources from a variety of domestic or foreign factors. The resources and business field of the business are not dependent on national factors but also international factors. Liberalization will increase efficiency for insurance companies to compete globally. Then, it is necessary to increase innovation in order to process business more efficiently. Model I is expected to explain the positive effect of insurance company liberalization on innovation that has been implemented. On the other hand, liberalization is also aimed at increasing the power of competition in the insurance industry.

It is hoped that increased liberalization in insurance companies will increase the efficiency of the company, and will increase the competition power of insurance companies. Model II is expected to explain the positive effect of insurance company liberalization on competition in the insurance industry. Increased efficiency will also lower costs and increase the company's profits. Performance improvements are analyzed in Model III. It is hoped that increased liberalization in insurance companies will increase the efficiency of the company and will further improve the performance of insurance companies.

Innovation, competition, and performance are three measures of the company's success. However, these three variables indicate a different scope of business issues. Innovation is a corporate strategy to create business creativity but requires regular development of large technologies. For small companies, low innovation costs can increase the scale of the economy, but large company innovations have low economies of scale. The competition shows a measure of the company's ability to compete among 
fellow companies in the same industry. The cost of innovation and the strength of the company's competition are expected to still improve performance through Return on Equity (ROE).

Literature Search: This research is supported by survey activities that aim to obtain an overview of the extent to which insurance companies use technology to support their business processes.

Research data: Secondary data is the primary data obtained from insurance data from 2006 to 2018. Types of data include (a) data on marketing and other operating expenses obtained from the income statement; (b) computer hardware investment data obtained from the financial position; (c) technology use data (insurance company individual data) obtain from non-investment recapitulation data. Insurance group consolidation data select according to its type, consisting of (1) reinsurance; (2) life insurance; and (3) general insurance. Data can be panel data where $\mathrm{i}=$ insurance company, $t=2006-2018$, and $j=$ insurance group.

Data analysis technique: In an empirical study, researchers separate different impacts for specific financial criteria without using dummy variables. The aim is to see the difference in the effect of insurance companies according to the level of profit, the amount of net premium income, and the net premium using Threshold Fegression analysis techniques. Threshold Fegression is used to select whether, at the high-profit level of the insurance company, the impact of LIB still shows the same direction as the company at a low-profit level; likewise, whether a company with a high amount of net premium income will have the same impact as an insurance company with a low amount of net premium income.

(a) Variable Innovation $_{j t}$ is selected from Table 1 to get the best and unbiased determinant variable. It needs to be done, considering the research must pay attention to adding variables and the omitted variable bias. Variable Innovation ${ }_{j t}\left(\operatorname{In}_{j t}\right)$ consists of sales innovation, underwriter innovation, and claims innovation. The notation $\mathrm{j}=$ insurance and $\mathrm{t}$ is 2015 to 2018 annual period.

$$
\begin{aligned}
\text { InnSales }_{j t} & =\frac{\text { Sales }_{j t}}{\text { Komp }_{j t}} \\
\text { InnPend }_{j t} & =\frac{\text { Pend }_{j t}}{\text { Komp }_{j t}} \\
\text { InnPeg }_{m t} & =\frac{\text { Peg }_{j t}}{\text { Komp }_{j t}}
\end{aligned}
$$

Table 1. Variable Model I: Innovation.

\begin{tabular}{ll}
\hline Label & List of Ratio Variables \\
\hline RKP1 & $\begin{array}{l}\text { Premium adequacy ratio to claim payment } \\
\text { Premium income (claims and benefits paid + unit } \\
\text { redemption statement) }\end{array}$ \\
\hline The ratio of the premium adequacy to payment of claims \\
and general expenses \\
$\begin{array}{l}\text { Premium income (claims and benefits paid + unit } \\
\text { redemption claims + marketing expenses + personnel } \\
\text { and management expenses + education and training } \\
\text { expenses + education and training expenses + general } \\
\text { and administrative expenses) }\end{array}$ \\
\hline RKP3 & $\begin{array}{l}\text { The ratio of the adequacy of premiums and investment } \\
\text { returns to payment of claims and general expenses }\end{array}$ \\
\hline RKP4 & $\begin{array}{l}\text { The ratio of the adequacy of premiums and investment } \\
\text { returns to payment of claims and general expenses }\end{array}$ \\
\hline RSA & Insurance session ratio \\
\hline RI & The ratio of investment to technical reserves \\
\hline
\end{tabular}


(b) Variable Comp it is selected from Table 2 to get the best and unbiased determining variable. $\mathrm{HH}$ measurement (Herfindahl-Hirschman index)

Table 2. Variable Model II: Competition.

\begin{tabular}{ll}
\hline Label & Name \\
\hline HH10 & Competition based on 10 companies with dominant premium income \\
\hline HH15 & Competition based on 15 companies with dominant premium income \\
\hline HH2 & Competition based on 2 companies with dominant premium income \\
\hline HH20 & Competition based on 20 companies with dominant premium income \\
\hline HH30 & Competition based on 30 companies with dominant premium income \\
\hline HH5 & Competition based on 5 companies with dominant premium income \\
\hline
\end{tabular}

(c) Variable Performance $_{i t}$ is selected from Table 3.

Table 3. Variable Model III: Performance.

\begin{tabular}{ll}
\hline Label & Name \\
\hline PendPremNett & The ratio of the amount of net premium income \\
\hline PremiNet & Net Premium Amount \\
\hline ROE & Return On Equity \\
\hline
\end{tabular}

(d) Variable $\mathrm{Lib}_{t}$ is selected from Table 4. Liberalization is simplified based on four modes of international trade according to the definition of the WTO (World Trade Organization), namely, Mode 1: Cross-border, Mode 2: Consumption abroad, Mode 3: Commercial presence, and Mode 4: Movement of natural persons. The measurement result is a composite of all the components of the Mode variable.

Table 4. Variable Liberalization.

\begin{tabular}{ll}
\hline Label & Name \\
\hline Lib1 & AIS11_2_Insurance indic_Density1_MODE3 \\
\hline Lib2 & $\begin{array}{l}\text { AIS9_1_Insurance business written abroad by brances Business } \\
\text { written abroad_MODE1 }\end{array}$ \\
\hline Lib3 & AIS8_1_Insurance business by domestic and foreign risks_MODE1 \\
\hline Lib4 & AIS7_1_Gross operating expenses_MODE3 \\
\hline Lib5 & AIS5_2_GIS_Insurance employees_MODE3 \\
\hline Lib6 & AIS5_1_GIS_NumberofInsuranceUndertaking_MODE3 \\
\hline Lib7 & BoP Business written in the reporting country_MODE3 \\
\hline Lib & Komposite \\
\hline
\end{tabular}

Review of Literature: Liberalization has resulted in the entry of the largest insurance companies in the insurance market and in the attraction of more foreign companies, which has resulted in tighter competition with local industry players. The level of competition increases the number of insurance plans that are innovative and more attractive, better customer service, and increased awareness of the importance of insurance. The adaptation of insurance liberalization aims to regulate and protect the interests of policyholders of the insurance industry [22]. Pope and Luen Ma (2008) explain that the interactive relationship divide by market concentration and liberalization related to profitability. In other words, the effect of market concentration on the profitability of the insurance market varies, 
and this depends on the degree of market liberalization. The high entry barrier for competitors facilitates the market's ability to concentrate on collusive behavior [31].

Innovation capability consists of four types of innovation: organizational innovation, process innovation, product and service innovation, and marketing innovation. By increasing innovation in the company, it can influence the innovation performance of the company itself [32]. Organizational innovation is implementing new organizational methods in company business practices, workplace organizations, or external relations. Corporate design can lead to improving business performance by reducing organizational management and transaction costs. Organizational innovation is related to administrative efforts, including efforts to update systems, procedures, and routines to encourage team cohesiveness, coordination, collaboration, information, and knowledge sharing practices [33]. The innovation process can reduce the productivity, business growth, and profitability of an organization [34]. Product or service innovation activities are ways of adapting to policies and changes in consumer culture. Work and service innovation activities take into account changes in line structure, legacy systems, and business processes aimed at boosting revenue growth, financial stability, and improving customer experience and facing business competition [35]. Marketing innovation is a form of applying new marketing methods that involve significant changes in design or packaging, product placement, and promotions and prices [32].

The impact of liberalization varies considerably in each organization or company, especially in company performance [36]. Large companies were initially more productive to gain more from financial liberalization [37]. Profits earn through the encouragement it provides to improve service quality [38]. In China, most had little impact on increasing and improving the productivity of enterprises, but still significant on improving social welfare after the liberalization of the insurance market [39]. Liberalization is promoted with competition [26].

The organization will seek to improve its annual performance and its ability to survive in the face of business competition. Also, the game creates organizational efforts to improve customer service. One of them is with effective advertising and relationship management. The existence of opportunities and potential is one of the driving factors for improving organizational performance and competition [22], whereas in the sales sector, company behavior leads to three levels of decisions that pursued, namely, reinsurance, sales efforts, and price [2].

\section{Results}

\subsection{Results of the Analysis of Model I: Innovation}

The main models of the innovation equation are:

$$
\operatorname{Inn}_{j t}=\alpha_{i}+\beta_{1} L_{i b}+\sum_{p=1}^{P} \delta_{p} \operatorname{IntVar1} 1_{p j t}+\sum_{k=1}^{K} \theta_{k} \operatorname{MacVar}_{k j t}+\varepsilon_{1 j t}
$$

An alternative to deepening the analysis for various high and low regime levels of specific economic variables (variable threshold) in this research will use Threshold Regression, in particular, Threshold Autoregressive (TAR) analysis first developed by Tong (Tsay, 2010). This TAR is called Self Existing Threshold Autoregressive (SETAR) because the method uses a dummy, where this dummy is determined first by setting a Threshold, then develops in several ways: Movement between regimes/states uses observable data where the typical TAR model. Model I above is developed into a non-linear equation SETAR with the Maximum Likelihood estimator. The research model will change to (Example for Model I):

$$
\begin{aligned}
\operatorname{Inn}_{j t}=\alpha_{i} & +\left[\beta_{11} \operatorname{Lib}_{j t}+\sum_{p=1}^{P} \delta_{1 p} I n t \operatorname{Var} 1_{p j t}+\sum_{k=1}^{K} \theta_{1 k} \operatorname{MacVar}_{k j t}\right] \Pi\left(k_{t} \leq \widetilde{k}\right) \\
& +\left[\beta_{21} L i b_{j t}+\sum_{p=1}^{P} \delta_{2 p} I n t \operatorname{Var} 1_{p j t}+\sum_{k=1}^{K} \theta_{2 k} M a c V a r 1_{k j t}\right] \Pi\left(k_{t}>\widetilde{k}\right) \\
& +\varepsilon_{1 j t}
\end{aligned}
$$


where, through this regression, we can get the threshold value $(\widetilde{k})$ and there is a change in the parameter values $\beta_{11}, \delta_{1 p}, \theta_{1 k}, \beta_{21}, \delta_{2 p}, \theta_{2 k}$ for each equation. Models II and III follow the same way of analysis.

\subsubsection{Sales Innovation}

The regression results of the equation below are arranged based on Model I, where the dependent variable is innovation. The formation of innovation variables with employee innovation indicators is carried out through a measure consisting of the ratio of the amount of net premium income to marketing costs. Sales innovation measures the achievement of the amount of Net Premium Income made by marketing. The use of applications and technology will increase the amount of net premium income. This ratio, if it gets smaller, indicates that there is an innovation made by marketing so that marketing costs are cheaper. Designs can be in the form of using supporting applications, implementing communication through applications, and implementing candidate surveys through applications.

Table 5 is the observational data for the period Q1 2015 to Q4 2018. The top row shows the dependent variable Model I, namely, innovation. At the same time, the second column is a list of the independent variables of each equation. This section lists several equations with variations in the dependent variable to reveal the impact of each of the World Insurance Liberation Index (ILI) variables. The LIB variable is the ILI composite index, while the other LIB is explained in the LIB Table. The bottom is the model identification row consisting of R2-Adj, F-stat, Sum square residual, and the amount of data available. A high LIB value indicates $\left(^{*}\right)$ that the level of insurance liberalization is getting higher. The negative impact of liberalization on sales innovation shows that a higher level of liberalization will encourage the use of sales innovations. It thus reduces the insurance company's marketing costs.

Threshold Analysis: Sales Innovations. Following are the results of processing sales innovation data using Threshold analysis, which is divided into three, namely, high, medium, and low net premium income with a threshold value of 2 . The dependent variable is LOG (INNSALES1) with the Discrete Threshold Regression method. With the candidate Threshold variables-PENDPREMNETT, PREMINET, and PROFIT_PENDPREMNETT (net premium income) variable is selected, which is the most efficient. Selection is made to determine the most appropriate variable as a threshold value for changes to occur.

From Table 6, it can be summarized as follows:

Table 7 shows that companies with low and moderate net premium income have a threshold value lower than 722,492. While high net premium income has a threshold value greater than $7,224,292$, a sales innovation threshold value that is lower than 722,492 indicates that the premium income is low and moderate. Requires sales innovation to improve work efficiency and insurance services.

The LIB coefficient $\left(^{*}\right)$ in Table 6 is analyzed as follows. Analysis of the Threshold Regression Model I show a difference in the impact of liberalization (LIB) on various levels of net premium income. At low and medium high net premium income, negative and significant liberalization coefficients are recorded. Empirical evidence suggests that increased liberalization is driving down the cost of sales innovation. However, at high net premium income, increased liberalization has not been able to lower the cost of innovation. Companies with high net premium income still need the development of innovation at high cost. Companies with high net premium income have not operated efficiently.

\subsubsection{Employee Innovation}

In Model I, the employee innovation indicator uses a measure consisting of the ratio of net premiums and employee costs. Employee innovation aims to measure the achievement of the net premium made by supporting or operational employees. 
Table 5. Regression results for Model I: Sales innovation.

\begin{tabular}{|c|c|c|c|c|c|c|c|c|c|c|c|}
\hline \multicolumn{3}{|c|}{ VD: LOG (INNSALES1) } & \multicolumn{3}{|c|}{ VD: LOG(INNSALES1) } & \multicolumn{3}{|c|}{ VD: LOG (INNSALES1) } & \multicolumn{3}{|c|}{ VD: LOG (INNSALES1) } \\
\hline & Coeff. & T-Stat & & Coeff. & T-Stat & & Coeff. & T-Stat & & Coeff. & T-Stat \\
\hline \multirow[t]{3}{*}{ LIB } & $-0.465^{*}$ & -3.622 & & & & & & & & & \\
\hline & & & LIB1 & -0.25 & -3.189 & & & & & & \\
\hline & & & & & & LIB2 & $-0.098 *$ & -2.096 & LIB3 & $-0.857^{*}$ & -4.85 \\
\hline RKP1 & 31.354 & 3.099 & RKP1 & 19.371 & 2.5 & RKP1 & 22.366 & 2.119 & RKP1 & 50.24 & 3.867 \\
\hline RKP2 & -37.104 & -3.229 & RKP2 & -24.04 & -2.703 & RKP2 & -26.961 & -2.239 & RKP2 & -57.792 & -3.925 \\
\hline RKP3 & -33.102 & -3.449 & RKP3 & -21.789 & -2.959 & RKP3 & -24.631 & -2.464 & RKP3 & -50.896 & -4.145 \\
\hline RKP4 & 39.162 & 3.587 & RKP4 & 26.823 & 3.167 & RKP4 & 29.566 & 2.588 & RKP4 & 58.683 & 4.206 \\
\hline $\mathrm{ROE}$ & 0.01 & 1.21 & ROE & 0.011 & 1.265 & ROE & 0.018 & 2.346 & $\mathrm{ROE}$ & 0.005 & 0.724 \\
\hline ER & 0 & -0.393 & ER & 0 & -1.612 & ER & 0 & -0.368 & ER & 0 & 1.531 \\
\hline SB & 0.1 & 1.623 & SB & 0.074 & 1.351 & SB & 0.117 & 2.059 & SB & 0.049 & 0.545 \\
\hline SBINTL & -0.174 & -1.732 & SBINTL & -0.129 & -1.169 & SBINTL & -0.317 & -2.684 & SBINTL & -0.221 & -2.673 \\
\hline C & 50.571 & 3.97 & C & 30.795 & 3.674 & C & 14.226 & 3.032 & C & 87.301 & 5.16 \\
\hline \multicolumn{2}{|l|}{$\begin{array}{l}\text { Adjusted } \\
\text { R-squared }\end{array}$} & 0.965 & & & 0.973 & & & 0.959 & & & 0.964 \\
\hline \multicolumn{2}{|c|}{ F-statistic } & 118.95 & & & 116.015 & & & 102.032 & & & 116.56 \\
\hline \multicolumn{2}{|c|}{ Sum squared resid } & 42.549 & & & 40.745 & & & 42.127 & & & 44.249 \\
\hline \multicolumn{12}{|c|}{ Periods included: 16} \\
\hline \multicolumn{12}{|c|}{ Cross-sections included: 3} \\
\hline
\end{tabular}


Table 6. Threshold Analysis Results: Sales innovation.

\begin{tabular}{|c|c|c|c|c|c|c|}
\hline \multirow[t]{2}{*}{ Variable } & \multicolumn{2}{|c|}{ PENDPREMNETT $<1,132,305$ (12 obs) } & \multicolumn{2}{|c|}{$7,530,814 \leq$ PREMINET $<3.490315 \times 10 \mathrm{~b} 3$ obs } & \multicolumn{2}{|c|}{$3.490315 \times 10 \mathrm{~b} \leq$ PREMINET $-11 \mathrm{obs}$} \\
\hline & Coefficient & Prob. & Coefficient & Prob. & Coefficient & Prob. \\
\hline LIB & $-0.478849 *$ & 0.0388 & -0.390940 & 0.0677 & -0.143463 * & 0.3242 \\
\hline RKP1 & 33.22161 & 0.1011 & 421.5120 & 0.0000 & 3.312859 & 0.7788 \\
\hline RKP2 & -36.21030 & 0.0847 & -465.3388 & 0.0000 & -3.314343 & 0.8072 \\
\hline RKP3 & -33.28669 & 0.0822 & -403.7938 & 0.0000 & -6.530953 & 0.5600 \\
\hline RKP4 & 36.52106 & 0.0657 & 445.6719 & 0.0000 & 7.356553 & 0.5691 \\
\hline C & 49.54377 & 0.0326 & 42.84268 & 0.0466 & 16.45196 & 0.2604 \\
\hline \multicolumn{7}{|l|}{$\begin{array}{c}\text { Non-Threshold } \\
\text { Variables }\end{array}$} \\
\hline DEFL & 0.081016 & 0.0381 & & & & \\
\hline ER & 0.000120 & 0.2050 & & & & \\
\hline SB & 0.034954 & 0.6832 & & & & \\
\hline R-squared & 0.992663 & & & & & \\
\hline Adjusted R-squared & 0.987229 & & & & & \\
\hline S.E. of regression & 0.114199 & & & & & \\
\hline Sum squared resid & 0.352117 & & & & & \\
\hline Log likelihood & 49.85075 & & & & & \\
\hline F-statistic & 182.6601 & & & & & \\
\hline Prob (F-statistic) & 0.000000 & & & & & \\
\hline
\end{tabular}

“*" to denote the significance of coefficients. 
Table 7. Sales Innovations: Net Premium Income.

\begin{tabular}{cccc}
\hline No & Threshold Variable & Threshold Value & Total Data \\
\hline 1 & Low net premium income & value $<1,132,305$ & 12 \\
\hline 2 & Medium net premium income & $1,132,305<$ value $<7,224,292$ & 12 \\
\hline 3 & High net premium income & value $>7,224,292$ & 24 \\
\hline
\end{tabular}

Based on Table 8, the F-stat has a value above 81, which indicates that employee innovation statistically meets the criteria as a predictor in this model. $R-2$ values above $95 \%$ suggest that employee innovation can be explained by at least $95 \%$ by insurance liberalization. The negative impact of liberalization on employee innovation suggests that the higher the liberalization will encourage the use of employee innovation, which in turn can reduce employee costs.

Similarly, it needs to prove that Threshold Regression analysis is more efficient than linear Panel Data analysis. Table 8 shows the SSRs of various independent variables in columns 1 to 4 , which are $1.104,1.135,1.227$, and 1.31. In Table 9, it obtains that the SSR is 0.334822 . It proves that Threshold Regression is more efficient. The next analysis focus on Thresholds analysis.

Threshold Analysis: Employee Innovation. Following are the results of employee innovation data processing using threshold analysis, which is divided into three, namely, high, medium, and low net premium income with a threshold value of 2 . The dependent variable is LOG (INNPEG1) with the Discrete Threshold Regression method. With the candidate Threshold variables-PENDPREMNETT, PREMINET, and PROFIT-the PREMINET variable (net premium) is selected, which is the most efficient. Selection is made to determine the most appropriate variable as a threshold value for changes to occur.

Analysis results of employee innovation can be summarized as follows:

Table 10 shows that companies with low and moderate net premium income have a threshold value lower than 7,530,814. Meanwhile, high net premium income has a threshold value greater than $3.490315 \times 10 \mathrm{~b}$. A sales innovation threshold value that is lower than $7,530,814$ indicates that premium income is low and needs employee innovation to improve work efficiency and insurance services.

The LIB coefficient $\left(^{*}\right)$ in Table 9 is analyzed as follows. Analysis of the Threshold Regression Model I show a difference in the impact of liberalization (LIB) on various levels of net premium income. At low and medium high net premium income, negative and significant liberalization coefficients are recorded. Empirical evidence suggests that increased liberalization is driving down the cost of employee innovation.

\subsubsection{Educational Innovation}

The regression results of the equation in Table 3 are measured based on two measures: (1) the ratio of the total net premium income to employee costs (InnPend1) and (2) the rate of the net premium to employee costs (InnPend2) and education (InnPend). Educational innovation aims to measure the achievement or achievement of net premiums made through education in supporting insurance company operations.

Table 11 explains that the F-stat has a value above 37. It shows that statistical educational innovation can be used as a predictor in the model. $\mathrm{R}-2$ values above $89 \%$ indicate that educational invention can be explained by at least $89 \%$ by insurance liberalization. The negative impact of liberalization $\left(^{*}\right)$ on educational innovation shows that higher liberalization can encourage the use of educational innovations, which in turn reduce the cost of education. Similarly, it needs to prove that Threshold Regression analysis is more efficient than linear Panel Data analysis. Table 11 shows the SSRs of various independent variables in columns 1 to 3, 1.151, 1.115, and 40.586. In Table 9, it obtained that the SSR is 0.938711 . It proves that Threshold Regression is more efficient. The next analysis focuses on Thresholds analysis. 
Table 8. Model I regression results: Employee innovation.

\begin{tabular}{|c|c|c|c|c|c|c|c|c|c|c|c|}
\hline \multicolumn{3}{|c|}{ VD: LOG (INNPEG2) } & \multicolumn{3}{|c|}{ VD: LOG (INNPEG2) } & \multicolumn{3}{|c|}{ VD: LOG (INNPEG2) } & \multicolumn{3}{|c|}{ VD: LOG (INNPEG3) } \\
\hline & Coeff. & T-Stat & & Coeff. & T-Stat & & Coeff. & T-Stat & & Coeff. & T-Stat \\
\hline \multirow[t]{3}{*}{ LIB } & -0.219 & -2.691 & & & & & & & & & \\
\hline & & & LIB1 & -0.118 & -2.195 & & & & & & \\
\hline & & & & & & LIB2 & -0.038 & -1.551 & LIB3 & -0.106 & -0.929 \\
\hline RKP1 & -8.939 & -1.965 & RKP1 & -13.01 & -2.51 & RKP1 & -12.92 & -2.488 & RKP1 & -14.263 & -2.261 \\
\hline RKP2 & 9.121 & 1.715 & RKP2 & 13.53 & 2.238 & RKP2 & 13.599 & 2.242 & RKP2 & 14.165 & 1.939 \\
\hline RKP3 & 5.921 & 1.391 & RKP3 & 9.797 & 2.019 & RKP3 & 9.707 & 2.002 & RKP3 & 10.869 & 1.833 \\
\hline RKP4 & -5.926 & -1.184 & RKP4 & -10.12 & -1.78 & RKP4 & -10.19 & -1.792 & RKP4 & -10.607 & -1.538 \\
\hline $\mathrm{ROE}$ & 0.016 & 4.594 & ROE & 0.015 & 4.581 & $\mathrm{ROE}$ & 0.018 & 4.73 & $\mathrm{ROE}$ & 0.012 & 3.153 \\
\hline ER & 0 & 2.218 & ER & 0 & 1.092 & ER & 0 & 2.07 & ER & 0 & 1.915 \\
\hline SB & 0.175 & 5.514 & SB & 0.151 & 3.813 & SB & 0.175 & 5.04 & SB & 0.161 & 4.981 \\
\hline SBINTL & 0.247 & 4.274 & SBINTL & 0.265 & 3.675 & SBINTL & 0.184 & 3.102 & SBINTL & 0.214 & 3.509 \\
\hline C & 22.414 & 2.801 & C & 13.217 & 2.384 & C & 4.538 & 1.999 & C & 11.255 & 1.05 \\
\hline \multirow{2}{*}{\multicolumn{2}{|c|}{$\begin{array}{c}\text { Adjusted R-squared } \\
\text { F-statistic }\end{array}$}} & 0.952 & & & 0.961 & & & 0.95 & & & 0.962 \\
\hline & & 84.973 & & & 81.425 & & & 82.189 & & & 108.095 \\
\hline \multicolumn{2}{|c|}{ Sum squared resid } & 1.104 & & & 1.135 & & & 1.227 & & & 1.314 \\
\hline \multicolumn{12}{|c|}{ Periods included: 16} \\
\hline \multicolumn{12}{|c|}{ Cross-sections included: 3} \\
\hline
\end{tabular}


Table 9. Threshold Analysis Results: Employee Innovation.

\begin{tabular}{|c|c|c|c|c|c|c|}
\hline \multirow[t]{2}{*}{ Variable } & \multicolumn{2}{|c|}{ PREMINET $<7,530,814-24$ obs } & \multicolumn{2}{|c|}{$7,530,814 \leq$ PREMINET $<3.490315 \times 10 \mathrm{~b} 13$ obs } & \multicolumn{2}{|c|}{$3.490315 \times 10 \mathrm{~b} \leq$ PREMINET $-11 \mathrm{ob}$} \\
\hline & Coefficient & Prob. & Coefficient & Prob. & Coefficient & Prob. \\
\hline LIB & $-0.325254 *$ & 0.0652 & -0.356924 & 0.0422 & -0.326304 * & 0.0574 \\
\hline RKP1 & 57.97205 & 0 & -34.03584 & 0.0526 & 5.279284 & 0.4432 \\
\hline RKP2 & -61.3785 & 0 & 36.63726 & 0.0752 & -6.019823 & 0.4618 \\
\hline RKP3 & -57.41476 & 0 & 31.07446 & 0.0615 & -8.058089 & 0.2109 \\
\hline RKP4 & 60.75688 & 0 & -32.13764 & 0.0992 & 9.411641 & 0.2065 \\
\hline \multicolumn{7}{|l|}{$\begin{array}{c}\text { Non-Threshold } \\
\text { Variables }\end{array}$} \\
\hline DEFL & 0.064766 & 0.1655 & & & & \\
\hline ER & $-1.88 \times 10^{-5}$ & 0.7613 & & & & \\
\hline SB & 0.291417 & 0.0002 & & & & \\
\hline $\mathrm{C}$ & 34.11152 & 0.0541 & & & & \\
\hline R-squared & 0.979475 & & & & & \\
\hline Adjusted R-squared & 0.966735 & & & & & \\
\hline S.E. of regression & 0.10745 & & & & & \\
\hline Sum squared resid & 0.334822 & & & & & \\
\hline Prob (F-statistic) & 0 & & & & & \\
\hline
\end{tabular}

"**" to denote the significance of coefficients. 
Table 10. Employee Innovations: Net Premium Income.

\begin{tabular}{cccc}
\hline No & Threshold Variable & Threshold Value & Total Data \\
\hline 1 & Low Net Premiums & Value $<7,530,814$ & 12 \\
\hline 2 & Medium Net Premium & $7,530,814<$ value $<3.490315 \times 10 \mathrm{~b}$ & 12 \\
\hline 3 & High Net Premium & value $>3.490315 \times 10 \mathrm{~b}$ & 24 \\
\hline
\end{tabular}

Table 11. Regression results for model I: Educational innovation.

\begin{tabular}{|c|c|c|c|c|c|c|c|c|}
\hline \multicolumn{3}{|c|}{ VD: LOG (INNPEND1) } & \multicolumn{3}{|c|}{ VD: LOG (INNPEND2) } & \multicolumn{3}{|c|}{ VD: LOG (INNPEND) } \\
\hline & Coeff. & T-Stat & & Coeff. & T-Stat & & Coeff. & T-Stat \\
\hline \multirow[t]{3}{*}{ LIB } & $-0.088 *$ & -1.306 & & & & & & \\
\hline & & & LIB & -0.147 & -2.32 & & & \\
\hline & & & & & & LIB & $-1.247^{*}$ & -2.666 \\
\hline RKP1 & -14.91 & -2.582 & RKP1 & -9.999 & -1.827 & RKP1 & -280.846 & -5.265 \\
\hline RKP2 & 15.442 & 2.301 & RKP2 & 9.85 & 1.552 & RKP2 & 314.864 & 5.165 \\
\hline RKP3 & 11.55 & 2.126 & RKP3 & 6.894 & 1.335 & RKP3 & 267.509 & 5.301 \\
\hline RKP4 & -11.889 & -1.874 & RKP4 & -6.548 & -1.088 & RKP4 & -301.074 & -5.205 \\
\hline ROE & 0.001 & 0.208 & ROE & -0.001 & -0.258 & ROE & 0.043 & 1.184 \\
\hline ER & 0 & 1.707 & ER & 0 & 1.674 & ER & -0.002 & -3 \\
\hline SB & 0.106 & 1.41 & SB & 0.104 & 1.937 & SB & -0.386 & -0.739 \\
\hline SBINTL & 0.313 & 8.638 & SBINTL & 0.316 & 9.294 & SBINTL & 1.509 & 4.01 \\
\hline $\mathrm{C}$ & 12.4 & 1.788 & $\mathrm{C}$ & 18.593 & 2.974 & C & 150.265 & 3.493 \\
\hline \multicolumn{2}{|c|}{ R-squared } & 0.954 & & & 0.96 & & & 0.896 \\
\hline \multicolumn{2}{|c|}{ F-statistic } & 88.405 & & & 101.887 & & & 37.936 \\
\hline \multicolumn{2}{|c|}{ Sum squared resid } & 1.151 & & & 1.115 & & & 40.586 \\
\hline \multicolumn{9}{|c|}{ Periods included: 16} \\
\hline \multicolumn{9}{|c|}{ Cross-sections included: 3} \\
\hline
\end{tabular}

Threshold Analysis: Educational Innovation. The following are the results of processing education innovation data using threshold analysis, which is divided into three, namely, high, medium, and low net premium income with a threshold value of 2 . The dependent variable is LOG (INNPEND) with the Discrete Threshold Regression method. With the candidate Threshold variables-PENDPREMNETT, PREMINET, and PROFIT-the PREMINET variable (the net premium) is selected, which is the most efficient. Selection is made to determine the most appropriate variable as a threshold value for changes to occur.

Analysis results of education innovation can be summarized as follows in the Table 12:

Table 13 shows that companies with low and moderate net premium income have a threshold value lower than $1,404,683$. Meanwhile, high net premium income has a threshold value greater than $1,404,683$. A educational Innovation threshold value that is lower than 1,404,683 indicates that premium income is low and needs educational innovation to improve work efficiency and insurance services.

From the summary of the Threshold analysis for educational innovation in Table 10, it shows that companies with low and moderate net premium income have a threshold value lower than $1,404,683$. While high net premium income has a threshold value greater than $1,404,683$, the sales innovation threshold value is lower than 1,404,683, which indicates that premium income is low and needs educational innovation to improve work efficiency and insurance services.

The LIB coefficient in Table 12 is analyzed as follows. Analysis of the Threshold Regression Model I shows a difference in the impact of liberalization (LIB) on various levels of net premium income. At low net premium income, negative and significant liberalization coefficients are recorded. Empirical evidence shows that increased liberalization actually lowers the cost of innovation. At high net premium income, a positive and significant liberalization coefficient is recorded. Empirical evidence suggests that increased liberalization of high net premium income increases the cost of innovation. 
Table 12. Threshold Analysis Results: Educational Innovation.

\begin{tabular}{ccccc}
\hline Variable & \multicolumn{2}{c}{ PREMINET $<\mathbf{1 , 4 0 4 , 6 8 3 - 1 2}$ obs } & \multicolumn{1}{c}{$\mathbf{1 , 4 0 4 , 6 8 3} \leq$ PREMINET-36 obs } \\
\hline & Coefficient & Prob. & Coefficient & Prob. \\
\hline LIB & -2.62477 & 0 & 1.751394 & 0 \\
RKP1 & -11.7625 & 0.4139 & 15.70121 & 0.3849 \\
RKP2 & 12.90081 & 0.3688 & -22.1608 & 0.2868 \\
RKP3 & 11.49344 & 0.3959 & -13.0462 & 0.4443 \\
RKP4 & -12.9953 & 0.3343 & 16.77967 & 0.392 \\
C & 311.6062 & 0 & -114.66 & \\
\hline Non-Threshold & & & \\
Variables & & 0.2303 & \\
DEFL & -0.12384 & 0.1631 & \\
LOG(ER) & -4.49045 & 0.0001 & \\
SB & -0.64214 & & \\
R-squared & 0.994602 & & \\
Adjusted & 0.992312 & & \\
R-squared & 0.298416 & & \\
S.E. of regression & 0.938711 & & \\
Sum squared resid & -1.07153 & & \\
Log likelihood & 434.3275 & 0 & \\
F-statistic & & & \\
Prob (F-statistic) & & & \\
\hline
\end{tabular}

Table 13. Educational Innovation: Net Premium Income.

\begin{tabular}{cccc}
\hline No & Threshold Variable & Threshold Value & Total Data \\
\hline 1 & Low Net Premiums & value $<1,404,683$ & 12 \\
\hline 2 & Medium Net Premium & value $\geq 1,404,683$ & \\
\hline 3 & High Net Premium & value $>1,404,683$ & 24 \\
\hline
\end{tabular}

\subsection{Results of Model II Analysis: Competition}

The main model of the competition equation is:

$$
\operatorname{Comp}_{j t}=\alpha_{i}+\beta_{1} \operatorname{Lib}_{t}+\sum_{p=1}^{P} \delta_{p} \operatorname{IntVar} 2_{p j t}+\sum_{k=1}^{K} \theta_{k} \operatorname{MacVar} 2_{k j t}+\varepsilon_{2 j t}
$$

Model II is developed into a non-linear equation SETAR with the Maximum Likelihood estimator.

$$
\begin{aligned}
\operatorname{Comp}_{j t}=\alpha_{i} & +\left[\beta_{11} \operatorname{Lib}_{j t}+\sum_{p=1}^{P} \delta_{1 p} \operatorname{IntVar} 1_{p j t}+\sum_{k=1}^{K} \theta_{1 k} \operatorname{MacVar}_{k j t}\right] \Pi\left(k_{t} \leq \widetilde{k}\right) \\
& +\left[\beta_{21} \operatorname{Lib}_{j t}+\sum_{p=1}^{P} \delta_{2 p} \operatorname{IntVar} 1_{p j t}+\sum_{k=1}^{K} \theta_{2 k} \operatorname{MacVar}_{k j t}\right] \Pi\left(k_{t}>\widetilde{k}\right) \\
& +\varepsilon_{1 j t}
\end{aligned}
$$

Competition based on 15 (HH15) Dominant Net Premium Income companies. The regression results of the equation are arranged based on Model II, where the dependent variable is competition measured by Herfindahl Hirschman. The data obtained from a group of companies that are members of the Life Insurance, General Insurance, and Reinsurance Companies.

In Table 14, the analysis results show that the F-stat has a value above 102, indicating that the insurance liberalization variable is statistically sufficient to use as a predictor in the model, and other variables are considered constant. The $\mathrm{R}-2$ value above $90 \%$ indicates that the performance variable can be explained at least $90 \%$ by the variation of the insurance liberalization variable. Similarly, it needs to prove that Threshold Regression analysis is more efficient than linear Panel Data analysis. Table 8 shows the SSRs of various independent variables in columns 1 to 3, 1.079, 1.131, and 1.088. 
From Table 9, it was obtained that the SSR is 0.002020. It proves that Threshold Regression is more efficient. The next analysis focuses on Thresholds analysis.

Table 14. Results of Herfindahl Hirschman Analysis Model II: HH15.

\begin{tabular}{|c|c|c|c|c|c|c|c|c|}
\hline \multicolumn{3}{|c|}{ VD: HH10 } & \multicolumn{3}{|c|}{ VD: HH10 } & \multicolumn{3}{|c|}{ VD: HH10 } \\
\hline & Coeff. & T-Stat & & Coeff. & T-Stat & & Coeff. & T-Stat \\
\hline LIB1 & -2.888 & -0.873 & & & & & & \\
\hline LIB2 & & & LIB2 & 8.262 & 4.665 & & & \\
\hline LIB3 & & & & & & LIB3 & -47.821 & -5.109 \\
\hline RKP1 & -1988.52 & -4.314 & RKP1 & -1659.9 & -3.821 & RKP1 & -903.437 & -2.783 \\
\hline RKP2 & 2228.043 & 4.224 & RKP2 & 1857.177 & 3.756 & RKP2 & 1033.753 & 2.835 \\
\hline RKP3 & 1875.89 & 4.311 & RKP3 & 1568.917 & 3.809 & RKP3 & 854.361 & 2.735 \\
\hline RKP4 & -2107.86 & -4.219 & RKP4 & -1760.35 & -3.74 & RKP4 & -980.243 & -2.788 \\
\hline ROE & 1.306 & 3.719 & ROE & 0.857 & 2.537 & $\mathrm{ROE}$ & 1.021 & 3.731 \\
\hline DEFL & 8.717 & 6.31 & DEFL & 2.661 & 1.084 & DEFL & 14.533 & 7.937 \\
\hline ER & 0.005 & 0.75 & ER & 0.019 & 2.408 & ER & 0.014 & 2.903 \\
\hline SB & 1.846 & 0.292 & SB & 0.455 & 0.081 & SB & -2.572 & -0.619 \\
\hline SBINTL & -0.717 & -0.228 & SBINTL & -2.182 & -0.64 & SBINTL & -6.885 & -1.628 \\
\hline \multirow{3}{*}{\multicolumn{2}{|c|}{$\begin{array}{l}\text { R-squared } \\
\text { Sum Squared Reside. } \\
\text { S.D. dependent var }\end{array}$}} & 0.873 & & & 0 & & & 0.925 \\
\hline & & 1.079 & & & 1.131 & & & 1.088 \\
\hline & & 65.723 & & & 20.9 & & & 62.025 \\
\hline \multicolumn{9}{|c|}{ Periods included: 16} \\
\hline \multicolumn{9}{|c|}{ Cross-sections included: 3} \\
\hline
\end{tabular}

Threshold Analysis: Competition based on 15 companies (HH15) Net Premium Income. The following are the results of processing education innovation data using threshold analysis, which is divided into three, namely, high, medium, and low net premium income with a threshold value of 2 . The dependent variable is LOG (HH15) with the Discrete Threshold Regression method. With the candidate Threshold variables_PENDPREMNETT, PREMINET, and PROFIT_PENDPREMNET (net premium income) variable is selected, which is the most efficient. Selection is made to determine the most appropriate variable as a threshold value for changes to occur.

Results can be summarized as follows:

From the summary of the Threshold analysis for HH15 competition in Table 11, it shows that companies with low and moderate net premium income $\left(^{*}\right)$ have a threshold value lower than $1,641,387$. While high net premium income has a threshold value greater than $1,641,367$, the sales innovation threshold value is lower than 1,641,387, which indicates that premium income is low and moderate need to increase competition to improve work efficiency and insurance services.

The LIB coefficient in Table 15 is analyzed as follows. Analysis of Threshold Regression Model II shows the impact of negative liberalization (LIB) on low net premium income levels. The impact of liberalization (LIB) competition does not occur for companies with high net premium income. Empirical evidence suggests a significant liberalization coefficient in low net premium income companies. This shows that liberalization in companies with low net premium income has not been able to increase competition.

Table 16 shows that companies with low and moderate net premium income have a threshold value lower than 1,641,387. Meanwhile, high net premium income has a threshold value greater than $1,641,387$. A competition threshold value that is lower than $1,641,387$ indicates that premium income is low and needs competition to improve work efficiency and insurance services. 
Table 15. Threshold Analysis Results: HH15.

\begin{tabular}{|c|c|c|c|c|}
\hline \multirow[t]{2}{*}{ Variable } & \multicolumn{2}{|c|}{ PENDPREMNETT $<1,641,387$ (13 obs) } & \multicolumn{2}{|c|}{ 1,641,387 $\leq$ PENDPREMNETT (35 obs) } \\
\hline & Coefficient & Prob. & Coefficient & Prob. \\
\hline LIB & $-0.049896 *$ & 0.0000 & $-0.001502 *$ & 0.9156 \\
\hline RKP1 & -0.480382 & 0.2423 & 0.539049 & 0.3778 \\
\hline RKP2 & 0.483563 & 0.2546 & -0.640068 & 0.3653 \\
\hline RKP3 & 0.451161 & 0.2434 & -0.508845 & 0.3794 \\
\hline RKP4 & -0.452533 & 0.2569 & 0.608799 & 0.3624 \\
\hline $\mathrm{C}$ & 11.72585 & 0.0000 & 6.942042 & 0.0000 \\
\hline \multicolumn{5}{|l|}{$\begin{array}{c}\text { Non-Threshold } \\
\text { Variables }\end{array}$} \\
\hline DEFL & 0.010260 & 0.0002 & & \\
\hline ER & $3.91 \times 10 b$ & 0.9002 & & \\
\hline SB & -0.007457 & 0.0536 & & \\
\hline R-squared & 0.906736 & & & \\
\hline Adjusted & 0.867169 & & & \\
\hline $\begin{array}{l}\text { R-squared } \\
\text { S.E. of regression }\end{array}$ & 0.007825 & & & \\
\hline Sum squared resid & 0.002020 & & & \\
\hline Log likelihood & 173.7073 & & & \\
\hline F-statistic & 22.91667 & & & \\
\hline Prob (F-statistic) & 0.000000 & & & \\
\hline
\end{tabular}

Table 16. HH15 Competition: Net Premium Income.

\begin{tabular}{cccc}
\hline No & Threshold Variable & Threshold Value & Total Data \\
\hline 1 & Low Net Premiums & value $<1,641,387$ & 12 \\
\hline 2 & Medium Net Premium & value $\geq 1,641,387$ & - \\
\hline 3 & High Net Premium & value $>1,641,387$ & 24 \\
\hline
\end{tabular}

\subsection{Model III: Performance}

The main model used:

$$
\text { Kinerja }_{j t}=\alpha_{i}+\beta_{1} \text { Lib }_{t}+\sum_{p=1}^{P} \delta_{p} \operatorname{IntVar} 3_{p j t}+\sum_{k=1}^{K} \theta_{k} \text { MacVar3 }{ }_{k j t}+\varepsilon_{3 j t}
$$

Model III above is developed into a non-linear equation SETAR with the Maximum Likelihood estimator.

$$
\begin{aligned}
\text { Kinerja }_{j t}=\alpha_{i} & +\left[\beta_{11} \text { Lib }_{j t}+\sum_{p=1}^{P} \delta_{1 p} \operatorname{IntVar} 1_{p j t}\right. \\
& \left.+\sum_{k=1}^{K} \theta_{1 k} \operatorname{MacVar} 1_{k j t}\right] \Pi\left(k_{t} \leq \widetilde{k}\right) \\
& +\left[\beta_{21} L i b_{j t}+\sum_{p=1}^{P} \delta_{2 p} \operatorname{Int} \operatorname{Var} 1_{p j t}\right. \\
& \left.+\sum_{k=1}^{K} \theta_{2 k} \operatorname{MacVar}_{k j t}\right] \prod\left(k_{t}>\widetilde{k}\right)+\varepsilon_{1 j t}
\end{aligned}
$$

Performance: Net Premium Income. The regression results of the equation below are compiled based on Model III, where the dependent variable is performance. The formation of Performance variables carries out through several measures. This model uses the size of the total net premium income and ROE.

Based on Table 17, it is shown that the F-stat has a value above 47, indicating that all independent variables are statistically sufficient to be used as predictors in the model. The $\mathrm{R}-2$ value above $93 \%$ means that the variation in performance can be explained by at least $93 \%$ by insurance liberalization. 
The impact of positive liberalization on Net Premium Income ${ }^{*}$ ) shows that higher liberalization can encourage insurance companies to increase business efficiency and increase net premium income.

Table 17. Regression Results Model III: Performance.

\begin{tabular}{|c|c|c|c|c|c|}
\hline \multicolumn{3}{|c|}{ VD: LOG (PENDPREMNETT) } & \multicolumn{3}{|c|}{ VD: LOG (PENDPREMNETT) } \\
\hline & Coeff. & T-Stat & & Coeff. & T-Stat \\
\hline LIB1 & 0.671 * & 2.485 & & & \\
\hline LIB2 & & & LIB2 & $0.259^{*}$ & 2.394 \\
\hline \multicolumn{6}{|l|}{ LIB3 } \\
\hline RKP1 & -245.825 & -4.207 & RKP1 & -246.872 & -4.419 \\
\hline RKP2 & 273.289 & 4.089 & RKP2 & 274.185 & 4.294 \\
\hline RKP3 & 232.358 & 4.211 & RKP3 & 233.29 & 4.422 \\
\hline RKP4 & -259.432 & -4.101 & RKP4 & -260.201 & -4.304 \\
\hline DEFL & -0.576 & -5.534 & DEFL & -0.663 & -4.332 \\
\hline ER & -0.001 & -1.584 & ER & -0.001 & -1.605 \\
\hline SB & 0.277 & 0.83 & SB & 0.214 & 0.56 \\
\hline SBINTL & 0.891 & 2.447 & SBINTL & 1.474 & 6.291 \\
\hline $\mathrm{C}$ & -44.345 & -1.628 & C & -2.312 & -0.194 \\
\hline Adjusted R & & 0.93 & & & 0.935 \\
\hline F-statistic & & 58.105 & & & 47.362 \\
\hline Sum sc & resid & 40.119 & & & 42.242 \\
\hline \multicolumn{6}{|c|}{ Periods included: 16} \\
\hline \multicolumn{6}{|c|}{ Cross-sections included: 3} \\
\hline
\end{tabular}

ROE performance. The following Performance Measures are ROE. The results show agreement with the theory that increased liberalization will expand the business and increase profits.

From Table 13, it can be seen that the F-stat value is above 1.578, indicating that the statistical performance variable is sufficient to be used as a predictor in the model. Apart from that, other variables are considered constant. The $\mathrm{R}-2$ value above $63 \%$ indicates that the variation in the performance variable can be explained by at least $63 \%$ by the interpretation of the insurance liberalization variable.

Analysis of the LIB coefficient in Table 18 is as follows. Analysis of Threshold Regression Model III shows the positive impact of liberalization (LIB) on all levels of net premium income. This suggests that liberalization in insurance companies improves performance.

Table 18. ROE Performance Analysis Results.

\begin{tabular}{ccccccccc}
\hline & VD: ROE & \multicolumn{3}{c}{ VD: ROE } & \multicolumn{3}{c}{ VD: ROE } \\
\hline & Coeff. & T-Stat & & Coeff. & T-Stat & & Coeff. & T-Stat \\
\hline LIB2 & 2.809 & 4.252 & & & & & & \\
LIB2 & & & LIB2 & 2.809 & 4.252 & & & \\
LIB3 & & & & & & LIB2 & 2.809 & 4.252 \\
RKP1 & -16.926 & -2.88 & RKP1 & -16.926 & -2.88 & RKP1 & -16.926 & -2.88 \\
RKP2 & -2.661 & -0.906 & RKP2 & -2.661 & -0.906 & RKP2 & -2.661 & -0.906 \\
RKP3 & 18.727 & 4.292 & RKP3 & 18.727 & 4.292 & RKP3 & 18.727 & 4.292 \\
DEFL & -1.733 & -2.367 & DEFL & -1.733 & -2.367 & DEFL & -1.733 & -2.367 \\
ER & -0.005 & -2.308 & ER & -0.005 & -2.308 & ER & -0.005 & -2.308 \\
SB & -2.492 & -1.288 & SB & -2.492 & -1.288 & SB & -2.492 & -1.288 \\
C & -210.101 & -3.101 & C & -210.101 & -3.101 & C & -210.101 & -3.101 \\
\hline R-squared & & 0.632 & & & 0.6259 & & R-squared & 0.632 \\
F-statistic & 7.245 & & & 1.578 & & F-statistic & 7.245 \\
Sum squared resid & 658.748 & & & 658.748 & & & 658.748 \\
Periods included: 16 & & & & & & & \\
\multicolumn{2}{l}{ Cross-sections included: 3} & & & & & & \\
\hline
\end{tabular}


Statistical analysis to compare three models cannot be done because variables are dependent differently and have different units. Analysis between equations is carried out by comparing coefficients and conformity with theoretical studies.

\section{Discussion}

Based on the results of the Model I analysis, it revealed that liberalization had brought changes to the innovation strategy in the insurance industry in Indonesia. Unfortunately, in the Threshold model, the impact of liberalization has a negative and significant effect on the development of innovation in low-premium companies. Market liberalization encourages innovation in sales, employees, and education. Similar findings were stated by Lee and Lin (2016) that liberalization hurts insurance companies. Furthermore, this creates more risks that must be faced by insurance companies, especially in facing business competition and the global economy [10]. One reasonable strategy is to design contract agreements, determine fair pricing, and expand the market for insurance companies and the trend of changes in the insurance industry to be more efficient after liberalization so that industry players increase innovation, especially substantially positive technological changes. With market consolidation, increasing the scale of results coming from the ability to innovate can increase company efficiency [4].

These findings complement the previous results that state that liberalization affects financial innovation [40]. In other words, not only is financial innovation affected by liberalization, but also sales innovation, employee innovation, and educational innovation.

It is essential to create innovative capabilities in insurance companies. With the right business strategy, companies can improve their innovation capabilities, be it sales innovation, employee innovation, or educational innovation. Design can carry out through influence in business [41]. It is due to the transformation of knowledge, employee ideas into practical innovation depending on the level of delegation, willingness to provide resources and support from the leadership. Liberalization has an impact on innovation capabilities. Therefore, there is a need for encouragement to change stuff and resources into competitive advantages through the influence and practice of types of innovation in the company. Previous studies that support these findings reveal that business intelligence has a positive effect on knowledge sharing, innovation, and gaining competitive advantage [7].

The challenge for implementing innovation lies in training staff, integrating insurance products, and ensuring the best quality of service for customers. Apart from that, an insurance agent is also essential to achieve success and gain a competitive advantage [42]. Qualified and professional individuals are needed but, interestingly, retaining an agent is a challenge in today's competitive insurance business. Furthermore, previous researchers stated that a market-oriented culture should lead to superior performance [43]. By strengthening liberalization, it hopes that a market-oriented culture will increase innovation and success for insurance companies, especially domestic insurance.

The future of insurance determines by the improved performance of protection products, a refreshing display of innovation, the launch of packages tailored to competition and market needs, and maximum service levels [42]. In facing various challenges of liberalization, a long-term policy strategy is needed to develop markets. Pope and Luen Ma (2008) explain that after a shift in market structure due to the impact of liberalization, the market is institutionalized and is short-term due to the disruption of costs absorbed by the market [31]. What is clear is that liberalization has made market changes where the market is difficult to predict but can still anticipate the future by developing appropriate strategic plans.

On the other hand, the findings reveal that liberalization has a positive impact on performance and competition, as shown in the aggregate models II and III. It indicates that liberalization is an essential indicator of the sustainability of the insurance industry. Insurance companies in the broad category have a positive and significant impact. Meanwhile, insurance companies in the small group category have a negative effect. This finding is in line with the research conducted by Almajali, Alamto, and Al-Soub (2012), which suggests that size has a significant impact on the financial performance 
of insurance companies. The giant company gets more profit. Therefore, large companies have more resources, more professional accounting staff, and have more sophisticated information systems capable of producing high performance [14].

If the liberalization is significant, then performance and competition will increase [44], and vice versa; if the adaptation of liberalization does poorly, then the performance and competence will decrease. Further, it can be exacerbated if companies in developing countries have limited access to international capital markets [45]. Not only liberalization but also the opportunity to improve performance and obtain healthier competition is needed in the competitive behavior in the growing insurance market [46].

The results of the study are consistent with the view that regulations to promote welfare improvement will be minimal if not followed by increased significant liberalization [47]. Liberalization increases economic activity in all sectors and increases the real returns to both capital and labor [48]. Although the impact will be different for each company with high, low, and medium premium income, globally, liberalization can encourage increased productivity [26,49]. Taylor (2000) argues that, in the future, the liberalization strategy needs to seriously rethought [50]. Itis did consider that external liberalization, economic performance, and distribution are still not optimal. We Ge (1999) explains that the establishment of special economic zones can support economic liberalization. The designation of special economic zones, as carried out by the Chinese economy, serves to provide trade facilities and financial liberalization, increase resources, and promote economic growth and structural change [51].

The risks and benefits of liberalization are issues that continue to debated today [52]. Liberalization must be approached with care where an organization is needed to ensure law and enforcement of contracts as well as effective regulation and prudential oversight [21]. An adaptation effort to liberalization, innovation, performance, and competition in the development of the insurance sector has been made one of the priorities in Indonesia.

It is essential to design policy changes that can have a positive impact, namely: (1) creating the same market conditions for both private and state-owned insurance companies that lead to expanding market competition, growth in performance efficiency, and growth in the insurance market as a whole; (2) removing restrictions on state organizations to purchase state insurance products; (3) the choice of the insurance company must be made based on economic factors, not the type of ownership; expansion of the list of the kinds of voluntary insurance can include in the company's production costs; (4) creating a stimulus for capitalization growth in the insurance sector; (5) removing regulatory restrictions that delay the entry of foreign capital into the industry; (6) the integration of the insurance industry into the international market; and (7) democracy in the national reinsurance system and giving local insurance companies the right to choose reinsurance freely based on market factors [11]. What needs to be agreed upon is that the liberalization policy should lead to fair business competition, social justice, and protect local insurance companies from prospering the community as the values of Pancasila and the 1945 Constitution.

Based on the findings, the researcher conducted a deeper study to determine the differences and implications of these three models. First, in Model I, liberalization has a negative effect on low-income companies, while for companies with high opinions, it has a positive effect. This finding focuses on efforts to increase insurance growth by increasing innovation. The findings indicate that the positive implications only apply to large companies and not in small companies. Liberalization has not been able to maximize the growth of innovation in small insurance. Liberalization has more influence on innovation in large companies because it is driven by the large availability of resources. This may explain why it is quite difficult for small firms to compete with much larger firms on innovation, because large companies have a lot of available resources. Therefore, examining from previous research, various strategic efforts that focus on small companies must be carried out, especially by the government that holds liberalization policies.

Model II reveals that the existence of stronger liberalization encourages insurance companies to work more efficiently and increases net premium income. The results of the study of Model II 
focus on efforts to improve company performance. In contrast to Model I, which focuses on achieving innovation, in Model II, liberalization has positive implications for large and small companies in terms of company performance. Both big companies and small companies need the strength of liberalization to increase their income and work more efficiently.

The research results in Model III show the negative impact of liberalization on competition. In contrast to Model I and Model II, which focus on efforts to increase insurance growth in large and small companies, Model III emphasizes the effect of liberalization on competition in insurance companies. Strong liberalization has actually been able to make most companies reduce their competition. This is because liberalization can affect the reduction of market power due to the large number of companies in the insurance industry. Thus, implications may arise because strong liberalization is able to bring about fair competition.

In the end, this study succeeded in revealing that liberalization has an effect on innovation, performance, and the level of competition among insurance industry players in Indonesia based on insurance data from 2006 to 2018. Research on efforts to increase the growth of insurance companies by examining the effect of liberalization on three variables that focus on two categories of companies (large insurance companies and small insurance companies) have not been widely used by previous researchers. Previous research that examined the theme of liberalization using normative studies focused on a sustainable insurance industry strategy based on insurance and sustainability principles in the Financial Services Authority Regulation Number 76/PJOK.07/2016 concerning Increasing Financial Literacy and Inclusion in the field of financial services and/or society [53]. Another study examines the liberalization of the insurance sector, which has a positive effect on the sector by comparing the liberalization approach taken by BRIC countries (an acronym for Brazil, Russia, India, China, and South Africa) and India [54]. Other findings suggest that financial liberalization creates increasingly fierce competition and has a negative impact on financial stability [55].

Several previous findings highlight the growth efforts of insurance companies by examining the relationship between firm performance and insurance company governance [56] and international competition with the growth of the insurance market. Previous research by examining 25 insurance companies focused more on improving the financial performance of insurance companies by increasing the company's assets with liquids indicators, size, and competency index [14]. Previous research conducted on Life Insurance Companies of India (LIC) found that having only one life insurance company in India led to a complete monopoly. Following liberalization, private sector insurance companies were allowed to enter following the creation of the Insurance Regulatory and Development Authority (IRDA) and increased competition for insurance companies.

This research is more exclusively able to show more in-depth findings related to insurance companies' growth efforts. At the same time, it turns out that the impact of liberalization can be different for groups of small companies and large companies by using secondary data up to the last 12 years. Previous research used secondary data for the period 2000-20001 and 2014-2015 and showed different results, the market concentration of life insurance companies was low compared to other indices after liberalization [57]. It is clear that this research has a novelty from previous research and can provide broader implications in supporting the growth of insurance in Indonesia, which aims to encourage healthy competition and create social welfare.

\section{Conclusions}

Based on the results of data analysis and discussion, it the follow conclusions can be made. First, that the aggregate model has a negative and significant relationship between liberalization and innovation. However, in the Threshold Regression model, the impact of liberalization on design differs between low-premium firms and high-premium firms. In this case, the positive effects of adaptation liberalization are influenced by the availability of resources to large companies that are higher in optimizing innovation. Second, in the aggregate model, there is a negative and significant relationship between liberalization and competition. 
Meanwhile, in the Threshold model, the relationship between the two is significant. It indicates that liberalization can create healthy business competition between domestic and global companies. Third, insurance liberalization has a positive impact on company performance. It means that liberalization contributes to the effectiveness of better company performance.

In general, these findings reveal that the liberalization of global insurance finance can have a positive and significant impact on the development of the industrial sector in Indonesia. However, liberalization can be different for groups of small companies and groups of large companies.

From the findings, the expected implication is that the Indonesian government can consider taking policies that focus on building a more effective and efficient adaptation of liberalization by prioritizing three indicators of the insurance industry, namely: innovation, competition, and the performance of insurance companies. Not only encouraging progress for large companies but also low-income insurance companies. By knowing that these three variables can boost the company's survival and competitive advantage, insurance companies can pay more attention to innovation by improving the quality of human resources. In the future, further research can be carried out by adding other variables and with a broader scope so that the weaknesses of liberalization can identify and solutions found.

Author Contributions: Conceptualization, T.S., D.D., M.E., and R.R.; methodology, T.S. and M.E.; software, M.E.; validation, T.S., D.D., and M.E.; formal analysis, M.E., D.D., and T.H.D.; investigation, D.D., T.S., R.R., and T.H.D.; resources, T.H.D. and M.E.; data curation, T.S. and I.T.; writing-original draft preparation, T.S. and D.D.; writing-review and editing, T.S.; visualization, T.S. and M.E.; supervision, T.S.; project administration, T.S., D.D., and R.R.; funding acquisition, D.D. and R.R. All authors have read and agreed to the published version of the manuscript.

Funding: The Indonesia Financial Service Authority supported this work (grant no SP-2/MS.4210/PENG/2020).

Acknowledgments: The authors thank and extend their appreciation to the management department of the Research in Financial Service Sector, Indonesia Financial Service Authority for support project, and to Sekolah Tinggi Ekonomi dan Bisnis Islam (STEBI) Lampung University for helping explore this subject by inviting experts from related fields, providing map data, and support funding for this work of research.

Conflicts of Interest: The authors declare no conflict of interest.

\section{References}

1. Global Counsel LLP. The role of insurance in ASEAN markets. Prudent. Plc Website 2015. Available online: https:// www.prudentialplc.com/ /media/Files/P/Prudential-V3/content-pdf/analysis/asean-insurance.PDF (accessed on 10 August 2020).

2. Barros, P.P. Competition Effects of Price Liberalization in Insurance. J. Ind. Econ. 1996, 44, 267-287. [CrossRef]

3. Skuflic, L.; Galetic, F.; Greguric, B.A. Liberalization and Market Concentration in the Insurance Industry: Case of Croatia. Econ. Rev. J. Econ. Bus. 2011, 9, 61-75.

4. Gamarra, T. The effects of liberalization and deregulation on the performance of financial institutions: The case of the German life insurance market. Thünen-Series of Applied Economic Theory-Working Paper, No. 93; Institute of Economics, University of Rostock: Rostock, Germany, 2008; pp. 1-45.

5. Rajendran, R.; Natarajan, B. The impact of liberalization, privatization, and globalization (LPG) on life insurance corporation of India (LIC). Afr. J. Bus. Manag. 2010, 4, 1457-1463.

6. Chandrapal, J.D. Impact of liberalisation on Indian life insurance industry: A truly multivariate approach. IIMB Manag. Rev. 2019, 31, 283-297. [CrossRef]

7. Eidizadeh, R.; Salehzadeh, R.; Chitsaz Esfahani, A. Analysing the role of business intelligence, knowledge sharing and organisational innovation on gaining competitive advantage. J. Work. Learn. 2017, 29, 250-267. [CrossRef]

8. Goel, V.K. Impact of Liberalization on the Indian Insurance Industry. Int. J. Res. in Eng. Sci. Manag. 2020, 3, 195-198.

9. Fidrmuc, J. Liberalization, democracy and economic performance during transition. ZEI Work. Pap. 2000, 12. Available online: https://www.econstor.eu/bitstream/10419/39651/1/311939848.pdf (accessed on 10 August 2020). 
10. Lee, C.C.; Lin, C.W. Globalization, political institutions, financial liberalization, and performance of the insurance industry. N. Am. J. Econ. Financ. 2016, 36, 244-266. [CrossRef]

11. Glambotskaya, A. The Belarusian Insurance Market Characteristics in the Context of Economic Liberalization: Analysis and Policy Recommendations. Policy Pap. 2009, 1, 1-12. Available online: http://www.get-belarus. de/download/Beraterpapiere/2009/pp2009e01.pdf (accessed on 10 August 2020).

12. Hu, Y. Risk Management of Insurance Fund Use in the Large Asset Management Era. In Proceedings of the 3rd International Conference on Management, Education, Information and Control (MEICI 2015) Risk, Shenyang, China, 29-31 May 2015; Atlantis Press: Paris, France, 2015; pp. 757-762.

13. Connelly, J.T.; Limphayom, P. Board Characteristics and Firm Performance: Evidence from the Life Insurance Industry in Thailand Board Characteristics and Firm Performance. Chulalongkorn J. Econ. 2004, 16, 101-124.

14. Almajali, A.Y.; Alamro, S.A.; Al-Soub, Y.Z. Factors Affecting the Financial Performance of Jordanian Insurance Companies Listed at Amman Stock Exchange. J. Manag. Res. 2012, 4, 266-289. [CrossRef]

15. Shepotylo, O.; Vakhitov, V. Impact of Services Liberalization on rm Performance: Evidence from the Ukrainian rm-Level Data; Discussion Papers 45; Kyiv School of Economics: Kyiv, Ukraine, 2010; pp. 1-21.

16. EU-ASEAN Business Council. The Insurance Industry in ASEAN: Engine for Growth \& Social Cohesiveness. 2015. Available online: https://www.eurochamvn.org/sites/default/files/uploads/pdf/InsuranceAdvocacyPaper.pdf (accessed on 10 August 2020).

17. Bao, N.J.; Ramlan, R.; Mohamad, F.; Yassin, A.M. Performance of Malaysian insurance companies using data envelopment analysis. Indones. J. Electr. Eng. Comput. Sci. 2018, 11, 1147-1151. [CrossRef]

18. Huang, C.J.; Lin, J.R. Financial liberalization and banking performance: An analysis of Taiwan's former “Top 10 Banks". Appl. Econ. Lett. 2011, 18, 1111-1120. [CrossRef]

19. Reddy, A.A. Banking Sector Performance During Liberalization in India-A Review. SSRN Electron. J. 2011, 1-14. [CrossRef]

20. Ang, J.B. Savings mobilization, financial development and liberalization: The case of Malaysia. Rev. Income Wealth 2011, 57, 449-470. [CrossRef]

21. Detragiache, E.; Demirgüç-Kunt, A. Financial Liberalization and Financial Fragility. IMF Work. Pap. 1998, 98, 1. [CrossRef]

22. Gairola, V. A Comparative Study of Public and Private Life Insurance Companies in Post Liberalization Era. IJMBS Print Int. J. Manag. Bus. Stud. 2016, 6, 39-43.

23. Uddin, F.; Ali, M.A. New Business of LIC of India under Individual Assurance in the 21st Century: An Appraisa. Saudi J. Bus. Manag. Stud. 2017, 2, 584-590.

24. Kaushal, S.; Ghosh, A. Economic growth and the development of banking and insurance sector in the post-liberalized India: An empirical analysis. Int. J. Soc. Econ. 2010, 44, 2187-2207. [CrossRef]

25. Bargal, H.; Dashmishra, M.; Sharma, A. Performance Analysis of Small Scale Industries-a Study of Pre-Liberalization and Post-Liberalization Period. Int. J. Bus. Manag. Stud. 2009, 1, 17-26.

26. Boonyasai, T.; Grace, M.; Skipper, H., Jr. The Effect of Liberalization and Deregulation on Life Insurer Efficiency. Ph.D. Thesis, Georgia State Universit, Atlanta, GA, USA, 1999; pp. 1-35.

27. Khanal, D.R. Banking and insurance services liberalization and development in Bangladesh, Nepal, and Malaysia: A comparative analysis. In Proceedings of the Asia-Pacific Research and Training Network on Trade (ARTNeT); EconStor: Bangkok, Thailand, 2007; Volume 41.

28. Aseffa, Y., XI. Insurance services liberalization and capacity-building: The case of Africa. In Trade and Development Aspects of Insurance Services and Regulatory Frameworks; United Nations: New York, NY, USA; Geneva, Switerland, 2007; pp. 199-242.

29. Tsay, R.S. Testing and Modeling Threshold Autoregressive Processes. J. Am. Stat. Assoc. 1989, 84, $231-240$. [CrossRef]

30. Wooldridge, J.M. Applications of generalized method of moments estimation. J. Econ. Perspect. 2001, 15, 87-100. [CrossRef]

31. Pope, N.; Ma, Y.L. The market structure-performance relationship in the international insurance sector. J. Risk Insur. 2008, 75, 947-966. [CrossRef]

32. OECD. Annual Report 2005; OECD Publishing: Paris, France, 2005; ISBN 9264007822. 
33. Van Der Aa, W.; Elfring, T. Realizing innovation in services. Scand. J. Manag. 2002, 18, 155-171. [CrossRef]

34. Veugelers, R. The role of SMEs in innovation in the EU: A case for policy intervention? Rev. Bus. Econ. 2008, 53, 239-262.

35. Deloitte 2019 Insurance Outlook. Deloutte Cent. Financ. Serv. 2018. Available online: https://www2.deloitte. com/content/dam/Deloitte/us/Documents/financial-services/us-fsi-dcfs-2019-insurance-industry-outlook.pdf (accessed on 10 August 2020).

36. Paudel, R.C.; Jayanthakumaran, K. Financial liberalization and performance in Sri Lanka: The ARDL approach. South Asia Econ. J. 2009, 10, 127-156. [CrossRef]

37. Bas, M. Does services liberalization affect manufacturing firms' export performance? Evidence from India. J. Comp. Econ. 2014, 42, 569-589. [CrossRef]

38. Mumuni, A.G.; Luqmani, M.; Quraeshi, Z.A. Telecom market liberalization and service performance outcomes of an incumbent monopoly. Int. Bus. Rev. 2017, 26, 214-224. [CrossRef]

39. Leverty, T.; Lin, Y.; Zhou, H. Firm Performance in the Chinese Insurance Industry; Wharton Working Paper; Georgia State University: Atlanta, GA, USA, 2004.

40. Effiom, L.; Edet, S.E. Financial innovation and the performance of small and medium scale enterprises in Nigeria. J. Small Bus. Entrep. 2020, 1-34. [CrossRef]

41. Oanh, N.T. The Relationship between Innovation Capability, Innovation Type and Innovation Performance in FDI Enterprises in Vietnam. Int. J. Econ. Financ. 2019, 11, 28. [CrossRef]

42. Krishnamurthy, S.; Mony, S.V.; Jhaveri, N.; Bakhshi, S.; Bhat, R.; Dixit, M.R.; Maheshwari, S. Insurance industry in India: Structure, performance, and future challenges. Vikalpa 2005, 30, 93-119. [CrossRef]

43. Langerak, F.; Hultink, E.J.; Robben, H.S.J. The Impact of Market Orientation, Product Advantage, and Launch Proficiency...: EBSCOhost. J. Prod. Innov. Manag. 2004, 21, 79-94. [CrossRef]

44. Kaur Bawa, S.; Chattha, S. Financial Performance of Life Insurers in Indian Insurance Industry. Pac. Bus. Rev. Int. 2013, 6, 44-52.

45. Arestis, P.; de Paula, L.F. Financial Liberalization and Economic Performance in Emerging Countries; Springer: Berlin/Heidelberg, Germany, 2008; pp. 1-221.

46. Market, E.I. Chapter Four Liberalization, Consolidation and Competitive Behaviour in an Emerging Insurance Market. In Efficiency, Competition and Risk-Taking Behaviour in the Short-Term Insurance Market in South Africa; 2016; p. 73. ISBN 978-979-9474-57-5. Available online: https://open.uct.ac.za/bitstream/item/27718/thesis_ com_2016_alhassan_abdul_latif.pdf?sequ\#page=91 (accessed on 10 August 2020).

47. Gupta, N.; Anand, A.; Rana, S. Impact of Liberalization on the Insurance Sector in India. J. Serv. Res. 2015, 16, 1-37.

48. Konan, D.E.; Maskus, K.E. Quantifying the impact of services liberalization in a developing country. J. Dev. Econ. 2006, 81, 142-162. [CrossRef]

49. Arnold, J.; Javorcik, B.S.; Mattoo, A. The productivity effects of services liberalization: Evidence from the Czech Republic. J. Int. Econ. 2011, 85, 136-146. [CrossRef]

50. Taylor, L. External Liberalization, Economic Performance, and Distribution in Latin America and Elsewhere. World Inst. Dev. Econ. Res. 2000, 215, 1-47.

51. Ge, W. Special Economic Zones and the Opening of the Chinese Economy: Some Lessons for Economic Liberalization. Acta Ophthalmol. 1999, 27, 1267-1285. [CrossRef]

52. Demir, F. A failure story: Politics and financial liberalization in Turkey, revisiting the revolving door hypothesis. World Dev. 2004, 32, 851-869. [CrossRef]

53. Wikantari, M.A. Sustainable Strategy in Life Insurance Industry in Indonesia. In Proceedings of the UI Proceedings on Social Science and Humanities, Yogyakarta, Indonesia, 25-27 June 2019; Volume 3.

54. Ray, S.; Bandyopadhy, K.; Thakur, V. Liberalisation of Insurance Sector: An Analysis of India and Brics. Indian Counc. Res. Int. Econ. Relat. 2020. Available online: https://www.think-asia.org/bitstream/handle/ 11540/12580/Working_Paper_396.pdf?sequence=1 (accessed on 10 August 2020).

55. Muhamad Arifin, N.A.; Mohd Arifin, N.; Zulkufly Ramly, Z.; Hashim, M.J. The Role of Competition as a Mediator Between Financial Liberalization and Financial Stability. Adv. Bus. Res. Int. J. 2019, 5, 51. [CrossRef] 
56. Markonah, M.; Sudiro, A.; Rahayu, M. The Effect of Corporate Governance and Premium Growth on the Performance of Insurance Companies in Indonesia. Eur. Res. Stud. J. 2019, XXII, 367-383. [CrossRef]

57. Parida, T.K.; Acharya, D. Competition in Indian life insurance industry: Post liberalisation evidence. Int. J. Bus. Compet. Growth 2016, 5, 110. [CrossRef]

Publisher's Note: MDPI stays neutral with regard to jurisdictional claims in published maps and institutional affiliations.

(C) 2020 by the authors. Licensee MDPI, Basel, Switzerland. This article is an open access article distributed under the terms and conditions of the Creative Commons Attribution (CC BY) license (http://creativecommons.org/licenses/by/4.0/). 